\title{
Forced Displacement and the Crisis of Citizenship in Africa's Great Lakes Region: Rethinking Refugee Protection and Durable Solutions
}

\author{
LUCY HOVIL AND ZACHARY A. LOMO
}

\section{Abstract}

This article explores refugee protection and durable solutions in Africa's Great Lakes region by examining conflict, displacement, and refugees in the light of the crisis of citizenship. Drawing on empirical data from nine studies across the region, we scrutinize the causes of conflict and displacement and refugee policies and practice in the region through the lens of citizenship. First, we argue that the continued plight of many refugees in the region without durable solutions results, at least in part, from an endemic and systemic inability of many people in the region to realize citizenship in a meaningful way. This inability, we argue, is a significant contributor to the continued forced displacement of millions of people, with many still refugees, even after living in the host states for over three decades. Second, we argue that solutions are failing because discussions about the root causes of refugee influxes and movements often fail to capture the intricately connected historical, political, social, economic, religious, and legal factors that engender displacement. We submit that full and equal enjoyment of the rights and benefits of citizenship by all, including access to citizenship for refugees, is one means of resolving displacement and providing durable solutions to refugees.

\section{Résumé}

Cet article s'engage à explorer la question de la protection des réfugiés et les solutions durables dans la région des
Grands Lacs en Afrique en étudiant le problème du conflit, du déplacement, et des réfugiés à la lumière de la crise de citoyenneté. En nous basant sur des données empiriques provenant de neuf études à travers la région, nous examinons de près les causes du conflit et du déplacement, ainsi que les politiques et les pratiques portant sur les réfugiés, en utilisant l'optique de la citoyenneté. Nous postulons deux arguments principaux: premièrement, que le sort tragique continu de nombreux réfugiés dans la région dépourvus de solutions durables provient, du moins en partie, d'une incapacité systémique et enracinée d'un nombre important de personnes dans les pays concernés d'actualiser la citoyenneté d'une manière significative; cette incapacité, nous avançons, contribue considérablement au déplacement forcé continu de plusieurs millions d'individus, avec de nombreuses personnes vivant toujours dans leurs pays d'accueil comme réfugiés même après plus de trois décennies. Deuxièmement, nous soutenons que l'échec des solutions vient du fait que souvent les discussions sur les causes profondes de l'influx et des déplacements des réfugiés ne prennent pas en compte l'enchevêtrement complexe de facteurs historiques, politiques, sociaux, économiques, religieux, et juridiques à plusieurs niveaux qui engendre le déplacement. Nous proposons qu'une pleine et égale jouissance des droits et avantages de la citoyenneté de la part de tous, y compris l'ouverture de l'accès à la citoyenneté pour les réfugiés, serait un moyen possible de résoudre le problème du déplacement, et d'offrir aux réfugiés des solutions durables. 


\section{Introduction}

7 his article explores the intersection between citizenship and belonging and displacement and refugees in Africa's Great Lakes region. Africa's Great Lakes region, ${ }^{1}$ which witnessed genocide, displacement, and the massive production of refugees at the turn of the century leaves many questions unanswered. ${ }^{2}$ Why did the region implode? Why have thousands in the region remained refugees for over four decades with no solution in sight? And why have thousands more found a formal end to displacement only to be re-displaced? Without claiming to offer answers, this article seeks to widen debate ${ }^{3}$ by analyzing forced displacement and the search for durable solutions to the plight of refugees through the lens of citizenship. While not denying the role played by other factors, the article's central thesis is that the continued plight of many refugees in the region without durable solutions results, at least in part, from an endemic and systemic inability of many people in the region to realize citizenship in a meaningful way. This inability, the article contends, is a significant contributor to the continued forced displacement of millions of people. Furthermore, just as the failure by many to realize the benefits of citizenship is one major cause of displacement, ensuring parity in the enjoyment of its benefits is also one means to resolve it.

\section{Theory and Method}

We do not situate our analyses in any particular theoretical approach to citizenship. ${ }^{4}$ We theorize citizenship as a status, legal or otherwise, that designates full membership in a state or community with concomitant rights or entitlements and duties, including the right and duty to challenge inequality in that state or community. This provides the starting point for our analysis. Citizenship differs from nationality. Nationality is a status acquired by birth in a given country. A person is a national of a given country by birth, while a person is a citizen of a given country either by birth or registration or naturalization. Nationality as used in international law is concerned with the "belonging of a person to a state," between an individual and a sovereign state, which entitles that state to espouse claims on behalf of that national under international law. ${ }^{6}$ People may have multiple citizenships, although at international law a particular state's responsibilities or rights may take precedence in a particular encounter. The citizens of a given state may consist of a multiplicity of identities and nationalities that share a sense of belonging and common values and convictions associated with that state. Having full membership in a state or community brings with it benefits and costs, rights, and responsibilities.
However, while nationality is often the gateway to citizenship and therefore an important first step to ensure the legitimacy to belong, we argue that inclusion within a community or society needs to be about far more: inclusion has to take account of local and regional factors, in particular the arbitrariness and fluidity of colonial borders, increasing forced displacement, migration and mobility, and the ability of citizens to exercise citizenship rights and duties beyond the state of origin. Therefore, citizenship is also seen as a broader concept capable of absorbing new members beyond the nationality status of belonging to a group having the same culture, traditions, and history. While possessing citizenship as a legal status conferred by national citizenship law plays a crucial part, it does not automatically ensure access to and exercising rights as a citizen. Exclusionary tendencies continue to resist and deny membership to those considered "alien" or "foreign" to the locality defined by a particular nationality or ethnicity.

The research demonstrated how some groups and individuals negotiated their interests within the rigidly defined frameworks of belonging-as national citizens, ethnicities, or refugees-and found acceptance. These groups and individuals exercised what we describe as "empirical citizenship." Some were legally citizens but not indigenous to the locality, while others were refugees who legally were not citizens, and locally they did not belong there, and yet they found a way of being able to negotiate the social, economic, and political terrain in which they sojourned and found acceptance and exercised a level of mobility and participation in everyday citizenship activities beyond the national borders. We theorize "empirical citizenship" as a status of being accepted into a given community as a member, even if not originally from there, and being able to exercise citizenship rights such as social and economic rights and fulfil civic duties, including paying local taxes. The research demonstrates that "empirical citizenship" includes the ability to belong in the community in which people are living; and it often includes the realities of forms of belonging that cross borders. For refugees in particular, this involved some exercise of autonomy in making decisions about return, and those decisions often contradicted those of the officials who frame and determine when return is possible within a formal repatriation paradigm to be triggered by officialdom.

We observed that "empirical citizenship" challenges, within the context of the region, and Africa as a whole, a rigid notion of citizenship that is tied to the nation state. Refugees interviewed seem to opt for a form of flexible citizenship ${ }^{7}$ that allows them to manoeuvre the treacherous terrain of survival in order to optimize their resources for the good of themselves and their families. From this perspective, we wondered whether citizenship, in its traditional 
formulation, adequately interrogates the problems of belonging, identity, peace, and stability in the region. ${ }^{8}$

The main question throughout the research, therefore, was how citizenship and exclusion affect the creation of, experience of, and resolution to displacement. We theorized that the inability of many people in the region to realize citizenship in a meaningful way is a root cause of both conflict and displacement in the region and the ongoing failure to find solutions to exile.

To interrogate how citizenship and exclusion affect the resolution of displacement in the Great Lakes Region of Africa, we adopted a theoretical approach that allowed us to ground the inquiry within the social, economic, political, and legal contexts in which forced displacement and exclusion happens. Thus, a socio-legal, theoretical framework was adopted. It posits that any study, social or legal, should be grounded in its social, economic, political, and legal contexts and that analysis of any problem, legal or social, should be informed by data collected from the field. Qualitative methods of data collection were employed: open-ended questions were used in conducting one-on-one interviews with refugees, internally displaced persons, returnees, and civil society, and relevant officials in each of the seven countries where fieldwork was conducted; policy documents and articles on refugees, displacement, repatriation, and citizenship were also reviewed. ${ }^{9}$

As with any empirical study, some caveats are in order. First, as we used qualitative methods of data collection, some limitations are unavoidable. For example, although we interviewed a wide range of people, our interviewees represent only a small sample of whole populations, and therefore any generalizations we make must be read in context. In addition, interviews took place in their natural settings, and our study may therefore not be replicated. ${ }^{10}$ Second, the quality of our data depends, to some extent, on our individual research skills and may be prone to personal world views.

These limitations notwithstanding, however, we believe collecting data using qualitative methods provided us, first, with a more useful way of exploring the complexity of social, economic, and political dynamics of displacement in the region. Second, it provided us a better understanding and descriptions of the personal experiences of the people we interviewed about displacement, exclusion, and citizenship in the region. Third, we were better able to grasp local situations, conditions, and stakeholder interests and needs than would, for example, quantitative approaches, such as asking respondents to complete a questionnaire with "yes" or "no" answers to complex set of problems.

\section{Causes of Conflict and Displacement in the Great Lakes Region}

With the exception of Tanzania, all the countries in the region have generated refugees and IDPs in large numbers since independence, and all have hosted refugees. Hundreds of thousands remain exiled outside or within their country with no solutions in sight. Numerous theories have been advanced to explain why endemic refugee flows and internal displacement have occurred in the region and Africa as a whole. Dominant in the literature is the extent to which the impact and legacy of colonialism is a cause of conflict and displacement. The history and evolution of "citizenship" in the region, intertwined with the history of the emergence of the modern African state, is a turbulent one, reflecting many of the wider issues dominating the post-colonial discourse. Notions of belonging were irrevocably changed with the advent of colonialism, which clearly defined the jurisdiction of the state, redefined the parameters of power, ${ }^{11}$ and regulated the movement of people. ${ }^{12}$

Mamdani, for instance, argues that crises in Africa are manifestations of the crisis of the post-colonial state. ${ }^{13}$ His central thesis is that the fault lines of current political instabilities and conflicts on the continent lie in the processes of the formation of the colonial state, which, he contends, resulted in a bifurcated state based on political identities of race and ethnicity. The colonial regime crafted "institutionally entrenched discrimination" into the colonial state by a plurality of laws-one for master and subject races and another set of legal regimes for ethnic groups. ${ }^{14}$

The creation by the colonial regime of a bifurcated state with institutionally embedded political identities, discrimination, and prejudices is certainly crucial to our understanding of the current political crises in the region. However, it does not fully explain why most post-independence leaders, who were presumably aware of the flaws of the colonial state and the risks it portended, chose to perpetuate aspects of a system fashioned to exploit resources and protect colonial interests, instead of carrying out reforms that could have addressed past inequalities and captured the diversity of nationalities that made up the mosaic of the new states.

The failure by post-independence leaders to build democratic states with viable institutions that not only allowed free entry and exit to political power but also provided effective checks and balances to the abuse of power, alongside inclusive citizenship policies and laws, is a key factor in understanding post-independence political instability and conflict in the region. Many post-independence leaders in the region, and Africa as a whole (possibly with the exception of Julius Kambarage Nyerere of Tanzania), lacked 
a clear and encompassing vision for their new nations that sought to unite rather than divide; to build rather than destroy; to be inclusive rather than exclusive; and to be confident rather than insecure. ${ }^{15}$ Although there was much rhetoric about national unity by many African heads of state-such as post-independence leaders Jomo Kenyatta of Kenya, Idi Amin of Uganda, self-styled Emperor Bokasa of Central Africa, Mobutu Sese Seko of the former Zaire, and Robert Mugabe of Zimbabwe-in practice the domineering and coercive machinery of the colonial state was often replicated, with little tolerance for alternative views and dissent. Their politics and policies perpetuated inequalities and marginalization, in particular the polarization of citizens or communities along ethnic lines, which became a means of holding onto power.

Within this context, autochtone conceptions of belonging have thrived and become key determinants of citizenship. In autochthone understandings of citizenship the question of belonging is implicated by the question of who arrived and occupied a given territory first; and the question of who settled first is linked to the assertion of indigenousness of a particular group or society to the territory in question. ${ }^{16}$

Assertions or claims of indigenity in relation to a territory mean that other groups that are seen as immigrants or newcomers to the territory do not "belong": instead, they belong to their own "native" place to which they can return. In practice, however, this is not possible, given that many of the "newcomers," or "immigrants," or "settlers" have lived in the contested area for decades, if not centuries. And, as the research demonstrates, the turmoil and movement of people created by refugee flows in the region has intensified this debate.

In addition, the tendency by many commentators to attribute the causes of civil wars and political crises in Africa to cultural differences-and, in particular, to point to ethnicity as the scapegoat for most conflicts in Africais both flawed and misleading. It also risks imposing onto African realities solutions that not only treat the symptoms rather than the cause, but also assume that the causes of the problems are internal, thereby ignoring the role of external interests.

Therefore, in addition to the legacy of colonialism and the failure of the post-colonial state to address the inadequacies that it inherited, has been the inability of the postcolonial state to accommodate multiple forms of allegiance and belonging that would mitigate, rather than cause, conflict. Ekeh, in a 1975 seminal article, argues that there are two public realms in Africa that determine the "structure of modern post-colonial politics in Africa."17 One is based on "primordial groupings, ties, and sentiments," which "influence and determine the individual's public behaviour." 18
This aspect of the public realm is ethnically based and driven by moral imperatives, similar to the function of the private realm in Western states. ${ }^{19}$ The other public realm "is historically associated with the colonial administration and ... has become identified with popular politics in postcolonial Africa." It is defined in terms of "military, civil service, the police, etc." Ekeh contends that this aspect of the public realm "has no moral linkages with the private realm" and calls it "the civic public." He concludes, "The civic public in Africa is amoral and lacks the generalised moral imperatives operative in the private realm and primordial public," and political actors in the post-colonial state operate simultaneously in both public realms, namely the civic and primordial publics. ${ }^{20}$ The dialectical relationship between these two realms, in Ekeh's view, explains the political crises afflicting some states in Africa, ${ }^{21}$ with clear implications for the realization of citizenship.

Thus, we argue that many of the causes of conflict and forced displacement, such as human rights violations, the struggle over control of political and economic power, ethnic conflict and civil war, are symptoms of deeper and interconnected problems. In particular, the failure by most postcolonial leaders to reform the colonial state and reorganize power by creating viable institutions that allow free entry and exit to political power and socio-economic opportunities and resources, and therefore the failure to address citizenship in a way that allows it to accommodate multiple identities lies at the root of recurrent political instability and conflicts in the region.

The question, however, is how to reconcile or reverse the logic of exclusion and avoid conflicts and civil war. Would drafting new national constitutions help to reconcile these competing issues and interests in ways that would allow those in exile to either have the option of taking new citizenship in their country of exile, or create the conditions of "acceptance" necessary to return to their former country of habitual residence? And would it allow those at "home" to feel a sense of belonging that secures their interests and those of their children, thereby diffusing future conflict? And, importantly for the purpose of this article, does refugee policy reflect the realities outlined above?

\section{Current Refugee Protection Policy Response and Practice}

Refugee law and policy, though well established, fail to resolve the problem of forced displacement both in addressing the root causes of violence, and ensuring an end to exile. The conventional policy instruments on refugees are crafted with a mindset that conceives refugees as a problem that imposes a burden on their hosts and calls for burden-sharing amongst states. The three "durable solutions"-repatriation, 
local integration, and resettlement-reflect this problemcentric image of the refugee. The research focused primarily on the first two of these solutions, both of which are now discussed in turn.

\section{Repatriation and Citizenship}

Repatriation returns refugees to their country of origin or habitual residence. The 1951 Refugee Convention is silent on repatriation; ${ }^{22}$ it says nothing about its nature-voluntary or otherwise. Hathaway has argued that because the 1951 convention has not provided for voluntary repatriation, it is "wishful legal thinking to suggest that a voluntariness requirement can be superimposed on the text of the Refugee Convention." ${ }^{23}$ The requirement of voluntariness is found only in the statute establishing the Office of the UNHCR, which requires the high commissioner to facilitate voluntary repatriation. ${ }^{24}$ In addition, the Executive Committee (ExCom) of the Office of the UNHCR has adopted conclusions emphasizing the voluntary character of repatriation. ${ }^{25}$ From a legal positivist perspective, the statute of the Office of the UNHCR and ExCom conclusions are not treaties and therefore not positive law. ${ }^{26}$

By contrast, the 1969 AU Convention explicitly states that repatriation should be voluntary. ${ }^{27}$ And while there is disagreement on whether there is any legal basis at international law for the voluntary character of repatriation, ${ }^{28}$ we submit that in the context of Africa, the legal basis for the international and voluntary character of repatriation is article 5 of the 1969 AU Convention, which emphasizes the voluntary character of repatriation.

Repatriation in the literature is often discussed in relation to "safe return" and the right of return. ${ }^{29}$ It is never discussed explicitly in the context of citizenship, with emphasis on the status of the person being a refugee. We treat repatriation as part of the exercise of the right of citizenship and not merely the desired solution to the refugee as a problem. Repatriation has typically been touted by national and international policy-makers as the best solution. This focus on repatriation not only has implications for the role that the other solutions (resettlement and integration) play in dealing with problems faced by refugees and finding permanent solutions, but also ignores the realities experienced by refugees, especially when return is coerced under the dubious concept of "safe return."30 Increasingly, refugees have little choice in matters of repatriation. For instance, Rwandan refugees in Uganda, who were pressed to return to Rwanda, talked about their fear that return would not be voluntary, referring to previous repatriation experiences in which people have been forcibly repatriated. For some, it was the experience of being forced out of Tanzania in the late 1990s; for others it was coming under attack from the Rwandan army in the camps in eastern DRC; others had been forced out of Uganda in 2006. As one man said, "They told us that before the 31 July 2009, we had to return to Rwanda. People were afraid. We remembered Kabahinde and Kibati. And we remembered the forceful repatriation from Tanzania when a lot of people were hurt-some were decapitated and others were killed in road accidents." ${ }^{1} 1$ The current initiative was seen as a continuation of similar exercises: "I think this repatriation is forced. I remember what happened in Tanzania, Congo, Burundi. I remember what happened in Kibati in 2006. Those who want to go back, they can. You don't need a UNHCR convoy for that." 32

New leadership in the countries of origin and the end of open conflict are often assumed to constitute an end to the circumstances that forced refugees into exile, and refugees are put under varying types of pressure to return, from the threat of withdrawal of assistance to actual withdrawal or forcible return. For example, in 2011 the government of Tanzania forced Burundian refugees through a new screening process and more rigorously enforced regulations forbidding them from travelling more than four kilometres outside the refugee camp. ${ }^{33}$ When these measures proved ineffective in pressuring refugees to leave, cessation (withdrawal of refugee status) was formally invoked, and a forced return operation was undertaken.

A number of key findings on repatriation emerged from the research. The first focuses on the question of when repatriation is appropriate and how that can be determined. In exploring the views of Rwandan refugees living in Uganda in late 2009, at a time when the potential declaration of cessation was hanging over them, the research found that refugees were frightened about the prospect of returning to Rwanda, as indicated in the quotations above. The fears of the refugees highlighted the pitfalls in relying primarily on the absence of open conflict as a benchmark against which to promote return. Although many refugees will seek to return at the first sign of abating conflict, there will inevitably be huge variation within any group of refugees, and for many a lack of open conflict will not be enough. The assumption that all can return at once may lead to a lack of safety for those who are not ready to return voluntarily. Instead, the assessment of whether or not return is timely should be considered in terms of refugees' voluntary choices as citizens who can determine when it is risky for them flee and seek safety in exile, and when conditions are favourable for them to return home and they are able to renegotiate access to effective citizenship on return. Making this assessment will focus on political openness and factors such as good governance and effective systems of justice. It will also recognize variations within the refugee community: there may be situations in which the majority of refugees 
are able to recreate these bonds, but others are not able, as a result, for instance, of their political, ethnic, or religious profile. Consideration of these factors and a more individual approach to repatriation will more reliably predict when it is not only safe to return home, but when return will be a genuinely permanent solution.

Yet the findings showed that the governments of Rwanda and Uganda and the UNHCR in 2009 were ignoring these criteria. The government of Rwanda's arguments in favour of repatriation focused on the genocide and its immediate aftermath (particularly armed conflict up to 1998) as the main cause of exile. However, the findings showed that ongoing political repression in Rwanda was not only preventing many refugees from returning, it was generating new refugees: almost a quarter of all those interviewed had arrived in Uganda since 2001, indicating that the promotion of voluntary repatriation, much less invocation of the cessation clause, should be approached with caution.

The absence of armed conflict was also a key factor in motivating UNHCR and the government of Uganda to consider cessation (although at the level of the government of Uganda it is worth noting that it was never implemented). This approach failed to recognize that war and violence may profoundly reshape a polity and can create new threats to individuals who may continue to require protection as refugees. In fact, Rwandan refugees in Uganda described themselves as victims of a "war on individuals" by a repressive government, highlighting their desire to show the precariousness of their situation, but also its individualized nature.

Ultimately, successful repatriation genuinely reasserts the bond of citizenship between citizen and state, permitting the latter to protect the former and the former to engage in dialogue on the nature of the protection required. In this context, assessment of the appropriateness of return should focus on those elements that are most likely to determine the success of this renegotiation. Critical to this assessment are questions about governmental and societal discrimination, restrictions on freedom of movement, denial of property rights, access to justice, and exclusion from governance. Without the opportunity to re-establish the state and citizen bond and the realization of their full rights as citizens, therefore, refugees are likely to continue to resist return-and others who face similar exclusion will continue to flee. And critical to this assessment is the fact that it is the refugees themselves who will usually be in the best position to make the assessment of whether this bond can be re-established.

A second finding was the way in which citizenship provides a lens for negotiating how repatriation, when appropriate, takes place. Policy-makers and implementers often construct the repatriation of a refugee in a linear progression; it is typically understood as a single course of action in one direction: a refugee leaves exile, crosses a border, returns home, and reaches a basic level of reintegration. As they cross the border, refugees shed their refugee status, thereby becoming persons no longer of "concern" to the international community. Within this official process, repatriation looks like a primarily humanitarian enterprise. However, while this essentially humanitarian boxing of people and processes may be helpful inasmuch as refugees and returnees leverage the assistance it provides, the process is not only fundamentally at odds with the wider political and economic context and does not make sense of people's survival strategies, it also robs them of the autonomy to decide for themselves what is right. At worst, it undermines people's coping mechanisms: in trying to promote protection, narrow approaches to repatriation effectively limit or compromise it.

If viewed through the lens of citizenship, however, successful repatriation does not entail just stepping over a border: it is a long-term process of negotiated access to human rights protection and is strengthened by addressing threats to post-conflict recovery and reconstruction. It is highly complex and intimately connected with the political and economic context. From this perspective, the refugee is a citizen with autonomy to decide when and how to return home, which might involve several journeys between the country of exile and the home country and also establishing long-term relationships across the border long after the experiences of exile.

Our research with South Sudanese refugees in Uganda in 2010, in the midst of official repatriation, showed that refugees went to great lengths to take flexible approaches to repatriation. Some families spread themselves geographically, with a number of family members repatriating while others waited in Uganda, either to see whether stability would continue or to allow children to continue their education. Such coping strategies were found to have been crucial during South Sudan's escalating conflict. Taking a gradual approach was also seen as important, as it allowed some family members to rebuild and lay the groundwork for others to return.

This experience highlights the importance of flexible repatriation processes and, in particular, the importance of allowing refugees and returnees mobility in order to make the most appropriate decisions for themselves. To the extent that citizenship entails reforming links with communities, refugees and returnees need to be able to move within and between states as they renegotiate linkages and access to resources. As Long asserts, during repatriation and post-conflict reconstruction, "mobility offers a possible means to offset many of the weaknesses of physical return 
programmes by providing access to alternative social, economic and cultural resources outside of the state of origin that may benefit refugees, their families and communities, and their home state."34 From this perspective, repatriation policies should not undermine citizenship and the opportunities it offers to refugees when they choose to end their displacement.

Third, the findings demonstrated that the relationship between repatriation and citizenship may further be complicated by the local politics of belonging. While, at the national level, citizenship and belonging may be defined by citizenship legislation, at the local level citizenship may be defined differently. In some cases local structures may be more open. For example, self-settled (South) Sudanese refugees in Uganda paid local taxes in order to leverage greater acceptance at the local level. 35 In other cases, it can be more restrictive, with local communities insisting on criteria of "indigenousness" as the basis of belonging. In this context, repatriation is caught between civic understandings of belonging, localized ethnic forms of belonging and citizenship, and notions of indigeneity, as illustrated by a group of Kinyarwanda-speaking (Tutsi) Congolese refugees living in a camp in Rwanda in 2011. The right of this group to belong is particularly contested, with many Congolese insisting that the refugees are actually Rwandan. The official repatriation process that was being considered included a mechanism by which returnees would be formally vetted by local authorities to determine whether or not they belonged in the areas to which they were to return. This mechanism, while essentially problematic, represents a unique formalization of processes that usually take place in informal and poorly documented ways. The process proposed was an interesting model but cannot be assessed, because in practice it was never deployed.

In the absence of an actual process, those who were considering a return to DRC recognized that in order for return to be viable, they would need to negotiate their legitimacy to belong nationally and locally. Refugees talked about the need to return as recognized Congolese citizens and not as Tutsis or Kinyarwanda speakers. They saw that their group identity had become a major source of instability and that the ability to genuinely (re)engage with the state as a citizen would be a key factor in determining the safety and durability of their return. However, they recognized that national acceptance had limited salience if they were not also accepted in the local areas from which they came, where they had land and property. The interaction between local and national belonging, therefore, was seen as a key factor in determining the ability to return and re-access livelihoods.

Fourth, the research demonstrated that land is a vital link between repatriation and citizenship: citizenship and belonging are intricately intertwined with land ownership; and land ownership is rooted in local belonging. These connections were illustrated by the research carried out with Burundian returnees from Tanzania in 2009, while Burundi was going through long and painful reconstruction after decades of violence, political turmoil, and displacement. In this context, the research showed that land was fundamental in creating an authentic reinstatement of the bond between citizen and state that had been violently broken: its equitable and just distribution was key to the reconstruction, reconciliation, and peace-building then taking place in Burundi.

The government of Burundi's policy of encouraging returnees to share "their" land with those they found living on it at the point of return (land that may have been wrongly appropriated, but on which many had been living for over three decades) was creating tension between returnees and those who had not fled. In these areas, the government of Burundi faced an unwinnable challenge with land claimants building strong legal cases and not enough land to go around. Solutions needed to focus on relieving pressure by creating alternative ways providing what the population was seeking through land-livelihoods and belonging. In this way, access to land could be addressed through a process that would rebuild civic trust and ensure the genuine reintegration of these former refugees.

Repatriation, therefore, when viewed through a citizenship lens, opens discussion on a broad range of dynamics and issues, all of which are critical to the creation of longterm stability. Ultimately, the way in which repatriation takes place can either destabilize a fragile situation or contribute to breaking cycles of violence and displacement. In the case of the latter, the genuine rebuilding of the bond of citizenship and belonging at both a national and local level are key.

\section{Local Integration and Citizenship}

Although article 34 of the 1951 convention stipulates that "contracting States shall as far as possible facilitate the assimilation and naturalisation of refugees," local integration through obtaining citizenship of host states has not been a priority in the Great Lakes region. The UNHCR defines local integration as including legal, economic, and social elements. The legal element is defined as "the establishment of a legal framework in which refugees gradually attain a wider range of rights in the host State-possibly, but not necessarily, leading to full citizenship and naturalisation." 36 While recognition of the multiple elements of integration is positive, the fact that citizenship is not seen as a requirement is evidence of how hard it is to obtain in many parts of the world. It also raises questions about the durability of that integration without full citizenship. 
In the Great Lakes region, the prospects of refugees acquiring citizenship are limited. Citizenship is generally accessible by birth, registration, or naturalization, but in many cases, there are legal obstacles. In most of the Great Lakes region, citizenship by birth is accessible only on the basis of inheritance (jus sanguinis) and not on the basis of birth in the country (jus soli), so citizenship cannot be extended automatically to the children of refugees, even if several generations are born in exile. While this situation does leave open the possibility of accessing citizenship through either registration or naturalization, in practice this rarely happens. In Uganda, for instance, even after refugees have lived in the country for over three decades, their children and grandchildren born in Uganda are explicitly excluded from citizenship by registration. ${ }^{37}$ And while a person who has lived in Uganda for at least ten years can, in theory, apply for Ugandan citizenship by registration, he or she must have come to Uganda legally and voluntarily; $3^{38}$ this requirement automatically disqualifies refugees who came to Uganda involuntarily in response to war or fear of persecution in their countries more than thirty years ago. Refugees who have lived in Uganda for more than twenty years could explore the possibility to naturalize. 39 The Uganda Citizenship and Immigration Control Act defines the criteria for acquisition of citizenship by naturalization and does not exclude refugees. ${ }^{\circ}$ And crucially, the Refugee Act, 2006, also provides for refugees to acquire citizenship by registration, but only for "recognized" refugees. ${ }^{41}$

In most countries in the region it is theoretically possible for a refugee to naturalize, although there are many legal obstacles to doing so. In the DRC, for instance, naturalization requires approval by the National Assembly and the applicant must have performed "major services" to the country-criteria that few, let alone refugees, are likely to meet. In Rwanda, applicants for nationality must be free of "genocide ideology," a vague legal construct that has been used to persecute opponents. Other obstacles include requirements for very long periods of residency to apply for naturalization and filing fees that place the process out of reach of most refugees, even when they would otherwise qualify.

In other cases, political considerations become an obstacle, as was seen in the research from 2008 and 2013 on Burundi refugees who had been living in Tanzania since the 1970s. The government of Tanzania was offering citizenship to these refugees through naturalization, with the UNHCR covering the cost of filing, in order to ensure that refugees were able to access the process. Yet refugees were contesting the nature and quality of citizenship they had been offered. It came with a catch: to obtain their citizenship certificate, refugees were being asked to relocate to other areas of the country-a requirement with no justification under the law. They were being asked to leave their homes of the past three or four decades (a lifetime for most) and start again with people they did not know. The potential within national belonging, in this instance, was jeopardized by a rupture in local forms of belonging. Without their community structures around them, built through decades of exile, their coping mechanisms were going to be severely eroded and, for many, the inflexibility of the process undermined its potential.

Refugees were apprehensive about the extent to which citizenship on the basis of forced relocation would allow for full access to rights and, most crucially, the ability to secure their livelihoods. For the majority of those interviewed, therefore, the possibility of staying in Tanzania as legitimate citizens but retaining the potential to return to Burundi was the optimal outcome-and one that did seemed reasonable for a group of refugees who have spent almost four decades living in exile and uncertainty.

For the government and policy-makers, the ambivalence of refugees who were refusing the unique opportunity to gain Tanzanian citizenship on the basis of having to move from the settlement, or who were talking about the possibility of returning to Burundi in the future, was seen as unacceptable and difficult to understand. Policy-makers premise Tanzanian citizenship as both a permanent and exclusive national identity, and a "solution" that should end concerns about the availability of protection. From the perspective of the refugees, however, there was little evidence that either would be a panacea, fully addressing all rights, security, and livelihoods issues.

Although the issue has recently been resolved, inasmuch as the government of Tanzania is no longer making citizenship contingent upon relocation, the discussion that led to this decision reveals the tension between the refugees' understanding of citizenship and that of the Tanzanian authorities, and raises fundamental policy questions about the nature of citizenship in the context of a multiplicity of identities and ties. In particular, it demonstrates that while policy-makers generally see naturalization as the end point of integration, refugees see it as distinct from their "empirical citizenship," which is just beginning to be established and is influenced by, but distinct from, the offer of national citizenship.

One issue that came through as critically important in establishing empirical citizenship was the need for freedom of movement and residence. Not only are such freedoms critical in allowing refugees to seek out the place or places where they have greatest possibility to ensure their local belonging, it is also a gateway to other rights. For instance, refugees who are able to move freely are more likely to be able 
to access livelihoods. These principles are well reinforced by international law.

\section{Rethinking Durable Solutions in the Context of Citizenship}

Two main conclusions are drawn from this review of underlying causes of conflict-induced displacement in the Great Lakes and the status quo on policy instruments on durable solutions to the plight of refugees in the region and the role that citizenship could play in providing such a solution. First, post-independence leaders failed to reform the colonial state and reorganize political power to address discrimination, inequality, and politicized identities that were legally embedded within the colonial state. As a result, the default position-at least at a political level-appears to be the exclusion of those considered outsiders, rather than to make efforts to encourage their integration. A key consequence is failure to adopt citizenship policies and criteria that are inclusive, and that, in turn, explains why hundreds of thousands of refugees, despite living in exile for decades, are still unable to access citizenship. And even in exceptional cases such as Tanzania where refugees were offered citizenship-either as a result of pan-Africanist idealism or as a solution to ending refugee status and integrating them into Tanzanian society-it has been construed in inflexible terms, giving refugees limited space to organize their lives as citizens with multiple identities and sense of belonging.

Second, the way in which refugee policies have been implemented has paid inadequate attention to the dynamics of inclusion and exclusion that are a common feature in any context, not least where resources are limited. Instead of refugees being seen as an asset, their presence has consistently been constructed as a threat, ensuring that their status as outsiders is embedded in the humanitarian response (as opposed to a political response) to refugees.

Problems in both citizenship policy and the way in which the refugee regime is constructed and implemented within this context, conspire to reinforce these problems rather than resolve them, creating the cycles of violence and conflict that we continue to see in the Great Lakes. Instead, policies have exacerbated the trend of exclusion by isolating refugees in camps, restricting their movement, and offering limited resettlement places. This isolationist approach is reminiscent of the way in which colonial and post-independence rulers excluded "outsider" communities from the benefits of citizenship and established a patronage system that allowed those in power to manipulate and control political power to their advantage. Refugee policies have continued to see refugees as outsiders, as being not ethnically and/or historically connected to the countries in which they have sought refuge.
Indeed, the status of refugees as outsiders has been exacerbated by the humanitarian response to refugee issues. This bedrock of exclusion has had two negative consequences for refugees and their host communities. First, refugees, as objects of charity, are treated as passive victims who must be cared for and maintained by an elaborate international bureaucracy assisted by local actors. ${ }^{42}$ Second, many refugee groups have lived for decades without solutions to their plight, unable to integrate into the community. These "protracted refugee situations" have been blamed on the conditions in their country of origin rather than the inability for the host state and other interests to allow their inclusion. ${ }^{43}$ As a result, for decades refugee policies in the region and Africa as a whole have not only failed to provide the majority of refugees with solutions to their plight or address their aspirations, but have failed to benefit host communities in a meaningful way. As a result, refugee policy has failed for the same reasons that citizenship policies and laws in postindependence Africa have failed to avert the political crises that engulfed the region and Africa as a whole.

\section{A New Approach to Refugee Policy}

The way forward, we suggest, is a realignment of refugee policies in the region in a way that makes them inclusive, focusing on the dignity and resourcefulness of refugees. Refugee policies need to view refugees as citizens and rational actors, notwithstanding their displacement, who are best placed, either as individuals or in communion with others, to determine what their interests are and how to protect them. This would translate into a policy that promotes an organic interaction between refugees and host communities that starts at the onset of a refugee influx and allows both to mutually benefit from each other; that identifies potential areas of tension and encourages collaboration between both communities to identify ways of removing the cause of that tension; and that allows local actors to benefit from the economic and business opportunities that result from the presence of the refugees and thereby minimizes xenophobia.

Ultimately, however, both refugee and citizenship law and policy need to be realigned: refugee policy, as with citizenship policy, needs to shed its emphasis on fear, exclusion, manipulation, ethnicity, and historical ties to territory, and instead be rooted in values such as community, protection of strangers, equality, fairness, and justice that transcend the current preoccupation with refugees as a problem. Indeed, on the basis of these values, refugee hosting communities are often the first "humanitarian actors" to protect refugees: progressive refugee policy could tap into this goodwill instead of undermining it.

In addition to community value systems, international law, its weaknesses and inherent biases notwithstanding, 44 
in particular human rights law could provide some basis for realigning refugee policy. Article 26 of the 1951 convention, for example, stipulates that "each Contracting State shall accord refugees lawfully in its territory the right to choose the place of their residence and to move freely within its territory." This right is subject only to "any regulations applicable to aliens generally in the same circumstances." A general limitation to this right might be article 9 of the convention, which allows a contracting state, "in time of war or other grave and exceptional circumstances" to take "provisionally measures which it considers to be essential to the national security." But this provision does not give contracting states a free ride; it must relate to a particular refugee, "pending a determination by the Contracting State that the person is in fact a refugee and that continuance of such measure is in the interest of national security." Thus, refugee policy premised on the right to freedom of movement and choice of residence will give refugees agency and allow them to integrate in the communities in ways that benefit them and their host communities.

Related to the right to freedom of movement and choice of residence as a key aspect of a progressive refugee policy is the non-discrimination obligation imposed on states by some international human rights instruments. As stated above, current refugee policy is premised on a care and maintenance paradigm that requires refugees to be encamped with most of their rights restricted. Encampment on the basis of refugee status is a form of discrimination and offends the provisions of most international human rights instruments. Article 2 of the African Charter on Human and Peoples Rights, for example, stipulates, "Every individual shall be entitled to the enjoyment of the rights and freedoms recognized and guaranteed in the present Charter without distinction of any kind such as race, ethnic group, colour, sex, language, religion, political or any other opinion, national and social origin, fortune, birth or other status." Article 2 (1) of the International Covenant on Civil and Political Rights (ICCPR) categorically enjoins contracting states to "ensure to all individuals within its territory and subject to its jurisdiction the rights recognized in the present Covenant, without distinction of any kind, such race, colour, sex, language, religion, political or other opinion, national or social origin, property, birth or other status."

Thus, refugee and citizenship policies have much in common and can be reformed by adopting inclusive criteria already in existence within the repository of community value systems or international law and international human rights instruments.

\section{Conclusion}

The problem of conflict, displacement, and refugees in the region is, to a large extent, intertwined with the crisis of citizenship. There are theories advanced to explain the causes of the problem, including ethnicity, the legacy of colonial rule, the failure to reform the colonial state by post-colonial leaders, violations of human rights, and the logic of "sovereignty and state." While all these ideas shed some light on the causes of the problem, at the core of these factors is the logic of inclusion and exclusion. Seen from this perspective, the dialectic between civic public and primordial public, or civic citizenship and ethnic citizenship, or the logic of sovereignty and state, are simply manifestations of a predisposition to include or exclude others-a phenomenon that is by no means unique to Africa.

Access to and control of finite resources such as land and the mineral wealth in the region drive exclusion or inclusion. In particular, ethnicity and historical ties to territory are commonly used to either legitimatize an indigenous group's or de-legitimatize the newcomer's claim to access and control over these resources. This struggle for access to and control of these resources has forced ethnic identities to take on hardened and aggressive boundaries, which has inevitably resulted in conflict and its attendant ramifications.

The presence of refugees intersects with many of these dynamics. Yet policy instruments fail to address these issues, in particular through the ongoing emphasis on repatriation and encampment of refugees that ignores the relationship between return and the versatility of citizenship. Inextricably linked to this lack of success is the fact that de jure local integration is not considered a solution for refugees, even those who have lived in exile for extended periods of time, many for generations: most states in the region restrict access to their citizenship for refugees. The international processes initiated for the region, such as the International Conference on the Great Lakes Region, while resulting in broad policy instruments that addressed discrimination, racism, ethnicism, exclusion, and national unity, never tackled citizenship as an explicit problem and its connections with racism, ethnicism, exclusion, and national unity.

Current approaches to refugee protection and embedded structures are profoundly harmful in their outcome and continue to fail to adequately provide solutions to their plight. A radical reform of governance structures-locally, regionally, nationally, and internationally-that repeatedly fail the citizenry they claim to represent is urgently needed. 
Lucy Hovil is the senior researcher at the International Refugee Rights Initiative, where she has co-ordinated a research project on the linkages between citizenship, displacement, and conflict for the past seven years. She is also managing editor of the International Journal of Transitional Justice. She founded and ran the Research and Advocacy Department of the Refugee Law Project (Faculty of Law, Makerere University, Kampala) for eight years. The author may be contacted atlucy@hovil.co.uk.

Zachary A. Lomo is a graduate of Harvard Law School, Makerere University, and Law Development Centre, and is acting dean of School of Law, St. Augustine International University, Kampala, Uganda and a CIGI research student at Osgoode Hall Law School, York University. He is former director, Refugee Law Project (School of Law, Makerere University), 20012006. The author may be contacted at zac.lomo@gmail.com.

\section{Notes}

1 The region consists of the territory covering twelve states that are members of the International Conference on the Great Lakes Region (ICGLR): Angola, Burundi, Central African Republic, Republic of Congo, Democratic Republic of Congo, Kenya, Uganda, Rwanda, Sudan, South Sudan, Tanzania, and Zambia.

2 This is even after a whole international conference, the International Conference on the Great Lakes Region (ICGLR), was jointly called and institutionalized by the United Nations and the African Union to seek answers and permanent solutions. On the ICGLR, see its official website at http://www.icglr.org/index.php/en/. For a comparative analysis of the ICGLR, see, e.g., Charlotte Heyl, "The International Conference on the Great Lakes Region (ICGLR): An African CSCE?," Konrad Adenauer Stiftung International Reports 12 (2010): 87-105. On the work of the ICGLR Secretariat, see, e.g., Morten Boas, Randi Lotsberg, and Jean-Nuc Ndizeye, "The International Conference on the Great Lakes Region (ICGLR): Review of Norwegian Support to the ICGLR Secretariat" (2009), http:// www.norad.no/om-bistand/publikasjon/2009/the-international-conference-on-the-great-lakes-region-icglr--review-of-norwegian-support-to-the-icglr-secretariat/.

3 While there are numerous studies on forced displacement and the crises engulfing the region, fewer approach it explicitly from a citizenship perspective; see, e.g., World Bank, Forced Displacement in the Great Lakes Region: A Development Approach (Washington DC: World Bank, 2015); Tom Ogwang, "Armed Conflict and Forced Migration in the Great Lakes Region of Africa: Causes and Consequences," International Journal of Research in Social Sciences 4, no. 2 (2014): 147-61; Won Kidane, "Managing Forced Displacement by Law in Africa: The Role of the
New African Union IDPs Convention," Vanderbilt Journal of Transnational Law 44, no. 1 (2011): 1-85; Chris Huggins, Herman Mushara, Prisca Mbura Kamungi, Johnstone Summit Oketch, and Koen Vlassenroot, "Conflict in the Great Lakes Region: How Is It Linked with Land and Migration?," Natural Resource Perspectives 96 (2005): 1-4; Bonaventure Rutinwa, "Forced Displacement and Refugee Rights in the Great Lakes Region," African Journal of International Affairs 1, no. 2 (1998): 11-43. Our study flows from the first "Citizenship and Forced Migration in the Great Lakes Region" consultative meeting on co-organized by the Social Sciences Research Council and the International Refugee Rights Initiative, Kampala, Uganda, 2005.

4 A detailed discussion of the major theoretical approaches to citizenship is beyond the scope of this article. Generally, see, e.g., Thomas Humphrey Marshall, Citizenship and Social Class (Cambridge: Cambridge University Press, 1950); Michael Mann, "Ruling Class Strategies and Citizenship," Sociology 21, no. 3 (1987): 339-54; Bryan S. Turner, "Outline of a Theory of Citizenship," Sociology 24 , no. 2 (1990): 189-217. For a collection of essays by leading theorists on citizenship, see, e.g., Ronald S. Beiner, ed., Theorizing Citizenship (Albany: State University of New York Press, 1994). For an economics approach to citizenship, see, e.g., Graziella Bertocchi and Chiara Strozzi, "The Evolution of Citizenship: Economic and Institutional Determinants," Journal of Law and Economics 53, no. 1 (2010): 95-136.

5 See, e.g., The Hague Convention on Certain Questions Relating to the Conflict of Nationality Laws, 12 April 1930 in 179 LNTS 89 and 24 AJIL (Supplement) (1930).

6 See, e.g., Nottebohm Case (Second Phase), Judgment of April 6th, 1955: ICJ Reports, p. 4; for a discussion of this case, see, e.g., Joseph L. Kunz, "The Nottebohm Judgment (Second Phase)," American Journal of International Law 54 (1960): 536-71.

7 See, e.g., Aihwa Ong, Flexible Citizenship: The Cultural Logics of Transnationality, 2nd ed. (Durham, NC: Duke University Press, 1999).

8 See, e.g., Saskia Sassen, Territory, Authority, Rights: From Medieval to Global Assemblages, 2nd ed. (Princeton, NJ: Princeton University Press, 2008).

9 Instead of having separate sections present and discuss the findings, we decided to present them in a thematic way, allowing the voices of the people we interviewed to speak to the issues addressed in this article.

10 See, e.g., W. Wiersma, Research Methods in Education: An Introduction (Boston: Allyn \& Bacon, 200o).

11 A. Kraler, "The State and Population Mobility in the Great Lakes," Working Paper no. 4, Sussex Migration (2004): 10.

12 J. Herbst, States and Power in Africa: Comparative Lesson in Authority and Control (Princeton, NJ: Princeton University Press, 2000), 227. 
13 M. Mamdani, When Victims Become Killers: Colonialism, Nativism, and the Genocide in Rwanda (Princeton, NJ: Princeton University Press, 2001).

14 Ibid., 29.

15 See Zachary A. Lomo, "Regional or National Protection for Great Lakes IDps?," special issue, Forced Migration Review (December 2006): 25.

16 S. Jackson, "Sons of Which Soil? The Language and Politics of Autochthony in Eastern D.R. Congo," African Studies Review 49, no. 2 (2006): 95-123.

17 P.P. Ekeh, "Colonialism and the Two Publics in Africa: A Theoretical Statement," Journal of Comparative Studies in Society and History 17, no. 1 (1975): 92, 106.

18 Ibid., 92.

19 Ibid.

20 Ibid., 92, 93. Emphasis in the original.

21 Ibid., 93.

22 But article 33 of the convention prohibits the forcible expulsion or return (non-refoulement) of refugees to frontiers of territories where their rights and freedoms will be violated, see, 1951 Refugee Convention, 189 UNTS 137, 176.

23 James C. Hathaway, “The Meaning of Repatriation," International Journal of Refugee Law 9, no. 4 (1997): 551. Also see same arguments in Hathaway, The Rights of Refugees under International Law (Cambridge: Cambridge University Press, 2005), 917-53. For a criticism of this perspective, see, e.g., B.S. Chimni, "From Resettlement to Involuntary Repatriation: Towards a Critical History of Durable Solutions to Refugee Problems," Refugee Survey Quarterly 23, no. 3 (2004): 61.

24 See article 1, Statute of Office of the United Nations High Commissioner for Refugees.

25 See, e.g., Ехсом Conclusion No. 18 (1980); Excom Conclusion 40 (1985); and Ехсом Conclusion No. 101 (2004): Legal Issues in the context of voluntary repatriation of refugees.

26 See, Hathaway, Rights of Refugees, 917-20.

27 See article 5 (1) of the 1969 OAU Convention Governing Specific Aspects of Refugee Problems in Africa.

28 See, e.g., Hathaway, "Meaning of Repatriation"; Guy S. Goodwin-Gill, "Voluntary Repatriation: Legal and Policy Issues," in Refugees in International Relations, ed. Gil Loescher and L. Monahan (Oxford: Oxford University Press, 1989), 255; Guy S. Goodwin-Gill and Jane McAdam, The Refugee in International Law, 3rd ed. (Oxford: Oxford University Press, 2007), 492-7; Chimni, "From Resettlement to Voluntary Repatriation."

29 See, e.g., UNHCR, "Discussion Note on Protection Aspects of Voluntary Repatriation," 1 April 1992, EC/1992/SCP/CRP.3; also see, e.g., UNHCR, Handbook on Voluntary Repatriation: International Protection (Geneva: UNHCR, 1996).

30 See, e.g., Chimni, "From Resettlement to Voluntary Repatriation," 60-3.
31 Interview with refugee man, Nakivale refugee settlement, Uganda, 17 November 2009.

32 Interview with refugee man, Nakivale refugee settlement, Uganda, 18 November 2009.

33 International Refugee Rights Initiative and Rema Ministries, "An Urgent Briefing on the Situation of Burundian Refugees in Mtabila Camp in Tanzania," 10 August 2012, http://www.refugee-rights.org/Assets/PDFs/2012/ Mtabila\%2OFInAL.pdf.

34 Katy Long, "Home Alone? A Review of the Relationship between Repatriation, Mobility and Durable Solutions for Refugees," UNHCR Evaluation and Policy Development Services (2010). See also Oliver Bakewell, "Repatriation and Self-Settled Refugees in Zambia: Bringing Solutions to the Wrong Problems," Journal of Refugee Studies 13, no. 4 (2000): 356-73; and Lucy Hovil and Moses Chrispus Okello, "The Right to Freedom of Movement for Refugees in Uganda," in Refugee Rights: Ethics, Advocacy and Africa, ed. David Hollenbach (Washington DC: Georgetown University Press, 2008).

35 Lucy Hovil, "Self-Settled Refugees in Uganda: An Alternative Approach to Displacement?" Journal of Refugee Studies 20 (2007): 599-620.

36 UNHCR, "The Benefits of Belonging: Local Integration ptions and Opportunities for Host Countries, Communities and Refugees," http://www.unhcr.org/4e3276e26.html.

37 See article 12(1)(a)(ii), Constitution of Uganda.

38 See article 12(2)(b), Constitution of Uganda.

39 See article 13, Constitution of Uganda.

40 See section 16(5), Uganda Citizenship and Immigration Control Act, 1997 as amended.

41 See section 45 of the Refugee Act, 2006.

42 On this aspect, see, e.g., Michel Agier, Managing the Undesirables: Refugee Camps and Humanitarian Government (Cambridge: Polity, 2011), 199-210; Guglielmo Verdirame and Barbara Harrell-Bond, Rights in Exile: JanusFaced Humanitarianism (New York: Berghahn Books, 2005), 271-325.

43 See, e.g., Nathaniel H. Goetz, "Lessons from Protracted Refugee Situations," Working Paper No. 74, Centre for Comparative Immigration Studies, University of California, San Diego, April 2003; Executive Committee of the High Commissioner's Programme, "Protracted Refugee Situations," UN Doc No. EC/54/sC.CRP.14, 10 June 2004, para. 15.

44 See, e.g., Antony Anghie, Imperialism, Sovereignty, and the Making of International Law (Cambridge: Cambridge University Press, 2005); Jack L. Goldsmith and Eric A. Posner, The Limits of International Law (Oxford: Oxford University Press, 2007).

(C) Lucy Hovil and Zachary A. Lomo, 2015. This open-access work is licensed under a Creative Commons Attribution-NonCommercial 4.0 International License, which permits use, reproduction and distribution in any medium for non-commercial purposes, provided the original author(s) are credited and the original publication in Refuge: Canada's Journal on Refugees is cited. 